\title{
Macroeconomic Determinants of Foreign Direct Investment in WAEMU Countries: The Place of Electronic Communication
}

\author{
Madow Nagou \\ Faculté des Sciences Économiques et de Gestion, Université de Lomé, Lomé, Togo \\ Email: yvounagou@gmail.com
}

How to cite this paper: Nagou, M. (2016) Macroeconomic Determinants of Foreign Direct Investment in WAEMU Countries: The Place of Electronic Communication. $\mathrm{Mo}$ dern Economy, 7, 1601-1609. http://dx.doi.org/10.4236/me.2016.714142

Received: October 27, 2016

Accepted: December 11, 2016

Published: December 14, 2016

Copyright $\odot 2016$ by author and Scientific Research Publishing Inc. This work is licensed under the Creative Commons Attribution International License (CC BY 4.0).

http://creativecommons.org/licenses/by/4.0/ (c) (i) Open Access

\begin{abstract}
In order to contribute in boosting Foreign Direct Investment (FDI) in the West African Economic Monetary Union (WAEMU) countries, this article aims to empirically establish the role of various macroeconomic determinants in attracting FDI by focusing specifically on electronic communication. The empirical estimates are based on panel data covering the period 1996-2014. These data come from United Nations Conference on Trade and Development (UNCTAD) and World Development Indicators (WDI) databases. Inspired from Arellano-Bond methodology, we estimate a fixed effects model for the sake of analysis. From the results, the electronic communication appears to be non-determinant for the attraction of FDI in the WAEMU countries. This result may be explained by the considerable level of electronic communication development prevailing currently in the union. In addition, it appears that economic dynamism captured through the gross domestic product, the weight of international trade and natural resources are the current key factors for attracting FDI in the union. Moreover, the increase in government spending tends to oust FDI.
\end{abstract}

\section{Keywords}

Electronic Communication, FDI, Fixed Effects Model, UEMOA

\section{Introduction}

Recent theoretical contributions on Foreign Direct Investment (FDI) in Africa actually emphasizes on capacity building of recipient countries to attract it in a well-integrated and profitable multinational environment. FDI flows to countries of the WAEMU (West African Economic and Monetary Union) have recorder, thanks to new governments' attraction strategies (generally improved economic climate of business and primarily the 
level of country governance) good performances. Indeed, these flows have accelerated at a rate of average annual growth of $19 \%$ over the period 2006-2013, against only $3.5 \%$ between 2000 and 2005. This reflects in particular the renewed interest in the mineral resources of the countries of the union, whose operation has become profitable thanks to the rise in international prices of commodities in the mid-2003. Nearly half of newly registered in the union flow (49.9\%) is for the mining sector. This sector is followed by the telecommunications (14.5\%), manufacturing (12\%), financial intermediation (9.2\%) and trade $(7.2 \%)$ [1]. Capital mainly from the euro zone, which represents $42.0 \%$ over the period 2006-2013 against 49.9\% between 2000 and 2005, followed by Asia, which recorded an increase of more than 7.0 percentage points between two sub-periods to achieve $22 \%$ of the stock of FDI received in the union in 2015. Niger (23\%), Côte d'Ivoire (20\%), Mali (16.2\%) and Senegal (14.2\%) accounted for over two-thirds of flows received during the past six years in the union against respectively $0.6 \%, 42.3 \%$, $22.6 \%$ and $10.4 \%$ over the period 2000-2005 [2].

The inflow of direct investment capital has instilled an important dynamic to the mining sector, which has replaced the agricultural sector in terms of export earnings. Regarding the flows in the telecommunications field, they allowed a significant improvement in access to communications services, particularly with a subscription ratio of mobile phones per 100 inhabitants, which increased from 1.2 in 2000 to 80 in 2014. As for the banking sector, in line with the arrival of new foreign groups and induced effects of the renewed dynamism of the mining and telecommunications, important progress has been made, particularly in terms of increased deposits, credit to the economy and job creation. Besides the direct impact on the main beneficiary sectors for foreign direct investment, improvements are noted in terms of overall investment, the ratio in percentage of GDP increased by $1.3 \%$ between 2000 and 2005 to $2.5 \%$ on 20062013 [3].

However, analysis of the performance index of FDI (IPIE) of UNCTAD, which measures the ability of a country to attract and retain foreign investment, however, reveal that the amounts of FDI received by West African Economic Monetary Union (WAEMU) countries still low compared to other regions of Africa and the rest of the world on one hand, and on the other hand, to the needs of countries of the union. This relative weakness of the attractiveness of WAEMU countries is supported by the results of the World Bank report Doing Business 2013. In addition, between 2013 and 2015, there has also been a decline of $6 \%$ on average of FDI received by the Union [4].

Consequently, it is very important that the WAEMU countries rethink the good rate of foreign direct investment coming home to further boost their economies. The current debate focuses among economists focus on the fundamental determinants of the attraction of FDI with regard to induced benefits of FDI on growth and technological level of countries [4] [5]. Thus, the objective of this paper is to establish new factors influencing FDI in the current economic environment of the WAEMU countries by investigating the role of electronic communication. This is permanently needed by policymakers of the union in their attempt to attract more FDI. 
The remaining of the paper is organized into four sections. The second section outlines the work a theoretical analysis of the attraction of FDI and its fundamental determinants. The third section deals with the current empirical lesson for UEMOA. The fourth section concludes.

\section{Glance on the Determinants of Foreign Direct Investment}

The theory of the pull-factor (FDI attraction factor in host country) has set out two categories of key factors for attracting FDI in the host countries. These factors fall under economic factors and financial and political risk.

Regarding economic and financial factors, the GDP growth rate and openness to international trade is the empirical determinants that were most often highlighted. Thus, in his study on the determinants of FDI in Africa, [6] utilizes, among other variables, the GDP growth rate, illiteracy rate, the ratio of exports to GDP, an economic infrastructure variable ( number of telephone lines per 1000 people) and the ratio of urban population to total population. He noted that the most important factors are economic growth and the economic opening of the country to foreign trade. For the author, improvement of the business climate through aggressive trade liberalization can fuel the interest of foreign investors to a particular country. Although for many observers, the ability of African countries to attract FDI has mainly depended on their natural resources and the size of their markets, the implementation by a number of countries (Singapore, Ireland) policies pro-active may be an indication of increasing the attractiveness of the country [7] also shows that the level and growth rate of GDP has positive and significant impact on FDI flows in Uganda over the period 1981-1995.

In the same vein, [8] shows that the traditional determinants, namely the growth rate and openness have a positive significant impact on the attractiveness of African countries, result consistent with the basic investment theory. Meanwhile, [9] also finds relevant results for Morocco. He concludes that the market size, the cost of labor, the level of public investment, inflation, human capital and exports also positively influence the flow of FDI in Morocco.

Regarding the political risk, the relationship between political risk and FDI has been the subject of several studies whose conclusions diverge to some extent [10] find that political risk is an important determinant for countries that attracted the largest amount of FDI flows. For others who have drawn less, socio-political instability had a negative impact on investment. Similarly, [9] finds a positive impact of democracy on FDI and concludes that democratic countries have an effective advantage over autocracies about the relative attractiveness of FDI. By analyzing the survey data gathered in the countries of the Southern African Development Community (SADC), [11] identifies five main obstacles to FDI common to these countries. These factors are the unstable political and economic environment, the inefficiency of administration, corruption, lack of transparency and the high tax burden [12] also concludes that the lack of notable attractiveness of African countries is also explained by their lack of stability and predictability of policy and institutional. 
However, some studies such as [13] [14], in an analysis of the statistical relationship between FDI policies and risk inputs for five major African destinations of FDI (Nigeria, South Africa, Botswana, Ivory Coast and Swaziland) conclude that with the exception of South Africa, the political conditions had no impact on FDI flows. This can be explained by the fact that the political conditions in these countries are not too degraded to influence the attraction of FDI and that there would perhaps exist more interesting attraction factors for investors such as the wealth of natural resources, favorable economic climate.

In recent years, few studies have focused on the research of the determinants of FDI in WAEMU countries [15] looked at the variables of international capital flows in Togo. The results of his study covering the period 1965-1992 showed that the growth rate is a relevant factor in explaining the short-term private international capital flows to Togo from the significant positive sign obtained. Likewise, public spending have a positive effect with a lag of two years. [16], analyzing the determinants of FDI in the Ivory Coast shows that long-term variables are positively impacting the gross national income per capita rate of private investment, the variability in the rate of real effective exchange rates, trade openness rate and the ratio of external debt service in relation to exports. The political instability is found to influence negatively FDI flows.

The study of [17] is one of the first to consider the WAEMU countries. The author shows that human capital measured by the gross enrollment rate in primary and economic openness are the main determinants of FDI for WAEMU countries over the period 1996-2003. The standard of living, as measured by GDP per capita, has a relatively small impact, as well as the variability of inflation. However, this study does not take into account the impact of political instability factors in addition to the lack of reliable data.

To summarize, the various studies on the determinants of FDI in the countries of the world on one hand, and the countries of the WAEMU union in the other hand, have focused on a variety of variables. However, it should be noted that most of these studies lead to different results.

This study based on a panel data with special effects in the following section, using the maximum of information on key macroeconomic factors of attraction of FDI and added other crucial factors such as current electronic communication (mobile telephony, fixed telephony, Internet), the level of country governance and natural resources to expose current empirical lessons for UEMOA.

\section{Methodology}

The Arellano-Bond methodology specifies a dynamic model which allows for time-invariant country-specific effects. This seems plausible in the case of FDI, where variables outside the analysis, such as political regime and distance to home countries display little, if any, variation over the period of the analysis. The equation estimated is as follow:

$$
y_{i t}=\alpha+X_{i t}^{\prime}+u_{i}+v_{i t}
$$


where $y$ denotes FDI as a share of GDP, $X$ is the vector of macroeconomic and electronic communication variables, and $\mu$ represents the time-invariant country-specific effect. The variables included in the vector $\mathrm{X}$ are described in the Table 1 bellow. All the variables are taken in logarithm. The data used in the study are annual data covering the period 1996-2014. They come from UNCTAD and World Development Indicators databases.

\section{Empirical Analysis}

\subsection{Electronic Communication Index Construction}

The Electronic communication is captured through a composite index named "Electronic communication index". Indeed, we apply the Principal Component Analysis (PCA) method to analyse three indicators related to electronic communication (fix phone, mobile phone and internet users) to construct a proxy of Electronic communication. This proxy is supposed to represent the overall electronic communication development degree of the considered country. Both the Kaiser-Meyer-Olkin $\left(\mathrm{KMO}^{1}\right)$ measure of sampling adequacy and Bartlett's test of sphercity [18] indicated that all the three variables included for the factor analysis were relevant. The variables included in the PCA come from World Bank Database. The descriptive statistics of all variables are presented in Table 2.

\subsection{Empirical Estimation}

The choice between random and fixed effects models precedes estimation of panel data. To discriminate between the two estimation models we run the [19] specification test

Table 1. Variables description.

\begin{tabular}{cc}
\hline Variables & Description \\
\hline GDP & Gross domestic product \\
GCF & Domestic investment \\
NETWORKC_index & Electronic communication index \\
TRADE & Weight of international trade \\
INFLATION & Inflation rate \\
TAXREVPGDP & Fiscal pressure rate \\
GOV & Governance indicator \\
G & Public expenditure \\
LABORFORCE & Human capital \\
TNATRESRENTPGDP & Total rent of natural resources \\
\hline
\end{tabular}

Source: Author from literature review.

${ }^{1}$ Kaiser-Meyer-Olkin (KMO) is a statistics that measures the adequacy of a variable to be included in factoranalysis based on correlation and partial correlation. There is a KMO statistic for each individual variable, and their sum is the KMO overall statistic. KMO varies from 0 to 1.0 and KMO overall should be 0.60 or higher to proceed with factor analysis. If it is not, the lowest individual KMO statistic values will be adopted, until KMO overall rises above 0.60 . 
Table 2. Descriptive statistics.

\begin{tabular}{cccccc}
\hline Variables & Observation & Mean & Sd & Minimum & Maximum \\
\hline LFDI & 144 & 24.26424 & 1.606434 & 19.14252 & 26.70106 \\
LGDP & 152 & 28.43485 & 0.9965327 & 26.30879 & 30.3172 \\
LGCF & 152 & 26.69992 & 1.204354 & 23.38632 & 28.57608 \\
NETWORKC_index & 152 & 9.435985 & 11.69554 & 0.0542189 & 52.34948 \\
TRADE & 152 & 62.32142 & 18.54714 & 30.73252 & 125.0278 \\
INFLATION & 152 & 3.923751 & 8.381935 & -10.73023 & 80.89967 \\
TAXREVPGDP & 152 & 14.28416 & 1.843695 & 10.58548 & 20.01624 \\
GOV & 152 & -0.606026 & 0.3854924 & -1.492214 & 0.0283973 \\
LG & 152 & 26.58873 & 0.967056 & 24.44711 & 28.32049 \\
LLABORFORCE1 & 152 & 15.03097 & 0.7419559 & 13.03438 & 15.96035 \\
TNATRESRENTPGDP & 152 & 9.318028 & 5.11778 & 2.455116 & 31.6154 \\
\hline
\end{tabular}

Source: Author's calculations from UNCTAD and WDI databases.

where the null hypothesis is that the preferred model is the random effects versus the alternative the fixed effects. The results of this test applied to our study indicate that the fixed effects model is superior to the random effects model (Prob (Chi2) $=0.0212<$ 0.05). However, in order to shade light on the robustness of the results, we run in addition to the fixed effect model, the random effect model. But we focus on the fixed effects model results for analysis purpose. The results of the estimated models is presented in the Table 3.

\subsection{Results and Interpretations}

The analysis provides interesting results for WAEMU countries, results that have the potential to awaken many decision makers in the union. First, one has to note that the results from the fixed effects method are similar to the results of random effects with the same significances of the estimated coefficients of the variables. This is a strong signal of that the results obtained are robust. For in-depth analysis we will focus only on fixed effect model because it is the model retained by the Haussman test.

From the results, one can conclude that domestic investment, the rate of tax burden, governance, the level of human capital and the means of electronic communication are not significant. In reality, all these variables are determining the attraction of FDI. Thus, the non-significance may be explained by a threshold analysis, that is to say, it may exist a threshold on these variables, a threshold that the union countries might have already exceeded. Indeed, the continuous improvement of economic and institutional conditions in the countries of the union through economic convergence (the tax ratio not exorbitant and economically acceptable level improved governance of the union, an increase presence of the hand to work with the higher education level, inflation better controlled in the sub-region, the telecommunications industry's development) is today hailed by foreigners, so that those concerned variables are no longer crucial when 
Table 3. Results of the estimates.

\begin{tabular}{|c|c|c|}
\hline Variables & Fixedeffect model & Random effect model \\
\hline Constante & $\begin{array}{c}-53.75872^{\star * *} \\
(-3.40)\end{array}$ & $\begin{array}{c}-6.408142^{\star} \\
(-1.91)\end{array}$ \\
\hline LGDP & $\begin{array}{c}2.776375^{* * *} \\
(2.90)\end{array}$ & $\begin{array}{c}1.164803^{* * *} \\
(6.00)\end{array}$ \\
\hline LGCF & $\begin{array}{c}0.2118714 \\
\quad(0.88)\end{array}$ & $\begin{array}{c}0.191707 \\
(0.89)\end{array}$ \\
\hline NETWORKC_index & $\begin{array}{c}-0.0214175 \\
(-1.60)\end{array}$ & $\begin{array}{c}0.0012944 \\
(0.16)\end{array}$ \\
\hline TRADE & $\begin{array}{c}0.03725^{\star * *} \\
\quad(3.46)\end{array}$ & $\begin{array}{c}0.026246^{* * *} \\
(3.56)\end{array}$ \\
\hline INFLATION & $\begin{array}{c}-0.017176^{*} \\
(-1.90)\end{array}$ & $\begin{array}{c}-.0180743^{*} \\
(-1.88)\end{array}$ \\
\hline TAXREVPGDP & $\begin{array}{c}-0.126792 \\
(-1.61)\end{array}$ & $\begin{array}{c}0.0590837 \\
(1.09)\end{array}$ \\
\hline GOV & $\begin{array}{c}0.1895504 \\
(0.46)\end{array}$ & $\begin{array}{c}0.5528248 \\
\quad(1.46)\end{array}$ \\
\hline LG & $\begin{array}{c}-0.4593644^{\star \star} \\
(-2.47)\end{array}$ & $\begin{array}{c}-0.384126^{\star \star} \\
(-2.19)\end{array}$ \\
\hline LLABORFORCE1 & $\begin{array}{c}0.3312673 \\
(0.24)\end{array}$ & $\begin{array}{c}-0.0213173 \\
(-0.07)\end{array}$ \\
\hline TNATRESRENTPGDP & $\begin{array}{c}0.0552119^{* *} \\
(2.04)\end{array}$ & $\begin{array}{c}0.0919035^{\star * *} \\
(3.84)\end{array}$ \\
\hline Nombre d'observations & 144 & 144 \\
\hline $\mathrm{R}^{2}$ ajusté & $56.94 \%$ & $72.36 \%$ \\
\hline$F(10,126)$ & 16.66 & - \\
\hline Prob $>F$ & 0.0000 & - \\
\hline $\mathrm{F}(7,126)\left(\mathrm{u}_{\mathrm{i}}=0\right)$ & 5.63 & - \\
\hline Prob $>F\left(u_{i}=0\right)$ & 0.0000 & - \\
\hline Wald chi2 (10) & - & 348.21 \\
\hline Prob $>$ chi 2 & - & 0.0000 \\
\hline
\end{tabular}

Source: Author estimates from UNCTAD and WDI databases.

the FDI are directed in the union.

By contrast, the variables gross domestic product, government expenditure, human capital, fiscal policy, inflation, trade have significant impact on FDI. They can consequently continue guiding the union policy in terms of FDI attraction.

\section{Conclusions}

In this article, we analyzed the current macroeconomic determinants of FDI attraction in the WAEMU union. We base our analysis on a panel data from the period 1996- 
2014. Before estimations, the Hausman specification test allowed us to retain a more efficient model between random effects to the fixed effects. However, the two models were performed for the sake of robustness analysis.

The results are particularly meaningful. First, among the macroeconomic drivers of FDI attraction, domestic investment, tax pressure rates, governance, the level of human capital and the means of electronic communication are not significant in the WAEMU. In fact, the explanation is that these variables are not too considered by foreign investors today, given the current continuous improvement of economic and institutional conditions of the union. Thus, the current macro factors essential for attracting FDI in the union are retained economic dynamism and market size captured by GDP, the weight of international trade and natural resources.

Moreover, analyzing the results, a very significant new result has caught our attention. Public spending now tends to oust FDI in the union, given the current awareness of these governments to invest more in their economic sectors to better feed their public finances. And as foreigners have always wanted to invest abroad, FDI could also take a new economic shape today in the union and become public loans and transfers of technologies in which these economies still need to improve their performance.

In terms of economic recommendations, WAEMU countries should firstly increase their internal and national productions, make their products competitive in international markets, and accelerate the exploitation and development of their natural resources. They should also be more open to the outside. On the other hand, they must always continue to improve their economic and institutional conditions, business climate and always ensure better economic stability, political and institutional, to take full advantage of FDI and its induced effects. Periodic grants to multinational firms and easing the taxation system for the latter also allow the union to benefit normally more FDI. Moreover, even if the governments of the union, now eager to better feed their public finances, invest far more in their economic sectors, they should always try to attract FDI, especially those of large countries, which essentially have many technological economic benefits.

\section{References}

[1] BCEAO (2013) Evolution des investissements directs étrangers dans les pays de l'UEMOA. BCEAO.

[2] World Bank (2016) World Development Database. http://data.worldbank.org/products/wdi

[3] UNECA (2011) Industrial Policies for the Structural Transformation of African Economies: Options and Best Practices. Policy Research Paper No. 2. United Nations Economic Commission for Africa (UNECA), Addis Ababa.

[4] UNECA (2013) Making the Most of Africa's Commodities: Industrializing for Growth, Jobs, and Economic Transformation. United Nations ECA, Addis Ababa.

[5] Aitken, B.J. and Harrison, A.E. (1999) Do Domestic Firms Benefit from Foreign Direct Investment? Evidence from Venezuela. The American Economic Review, 89, 605-618. https://doi.org/10.1257/aer.89.3.605

[6] Mucchielli, J.-L. and Mayer, T. (2005) Economie Internationale. Hypercours Dalloz, Paris. 
[7] Pirotte, A. (2011) Econométrie des données de panel. Théories et applications. Economica, Paris.

[8] Kang, S.J. and Lee, H. (2011) Foreign Direct Investment and the Industrialization. The World Economy, 34, 313-329. https://doi.org/10.1111/j.1467-9701.2010.01324.x

[9] Botta, A. (2010) Economic Development, Structural Change and Natural Resource Booms: A Structuralist Perspective. Metroeconomica, 61, 510-539. https://doi.org/10.1111/j.1467-999X.2009.04077.x

[10] Murphy, K.M., Shleifer, A. and Vishny, R.W. (1989) Income Distribution, Market Size, and Industrialization. The Quarterly Journal of Economics, 104, 537-564. https://doi.org/10.2307/2937810

[11] Harrison, A. and Rodrìguez-Clare, A. (2010) Trade, Foreign Investment, and Industrial Policy for Developing Countries. Handbook of Development Economics, 5, 4039-4214. https://doi.org/10.1016/B978-0-444-52944-2.00001-X

[12] Hu, A.G. and Jefferson, G.H. (2002) FDI Impact and Spillover: Evidence from China's Electronic Textile Industries. The World Economy, 25, 1063-1076. https://doi.org/10.1111/1467-9701.00481

[13] Nicoletti, G., Golub, S., Hajkova, D., Mirza, D. and Yoo K. (2003) Policies and International Integration: Influences on Trade and Foreign Direct Investment. OECD Working Paper No. 359.

[14] Murphy, K.M., Shleifer, A. and Vishny, R.W. (1989) Industrialization and Big Push. Journal of Political Economy, 97, 1003-1026. https://doi.org/10.1086/261641

[15] Barbosa, N. and Eiriz, V. (2009) Linking Corporate Productivity to Foreign Direct Investment: An Empirical Assessment. International Business Review, 18, 1-13. https://doi.org/10.1016/j.ibusrev.2008.10.003

[16] Barrios, S., Görg, H. and Strobl, E. (2005) Foreign Direct Investment, Competition and Industrial Development in the Host Country. European Economic Review, 49, 1761-1784. https://doi.org/10.1016/j.euroecorev.2004.05.005

[17] Di Maio, M. (2009) Industrial Policies in Developing Countries: History and Perspectives. In: Cimoli, M., Dosi, G. and Stiglitz, J.E., Eds., Industrial Policy and Development. The Political Economy of Capabilities Accumulation, Oxford University Press, Oxford, 108-143. https://doi.org/10.1093/acprof:oso/9780199235261.003.0005

[18] Hair, J., Anderson, R., Tatham, R. and Black, W. (1998) Multivariate Data Analysis. 5th Edition, Prentice Hall International, London.

[19] Hausman, J.A. (1978) Specification Tests in Econometrics. Econometrica, 46, 1251-1271. https://doi.org/10.2307/1913827 
Submit or recommend next manuscript to SCIRP and we will provide best service for you:

Accepting pre-submission inquiries through Email, Facebook, LinkedIn, Twitter, etc. A wide selection of journals (inclusive of 9 subjects, more than 200 journals)

Providing 24-hour high-quality service

User-friendly online submission system

Fair and swift peer-review system

Efficient typesetting and proofreading procedure

Display of the result of downloads and visits, as well as the number of cited articles

Maximum dissemination of your research work

Submit your manuscript at: http://papersubmission.scirp.org/

Or contact me@scirp.org 